\title{
Reduced fecundity in a deep-water population of the giant scallop Placopecten magellanicus in the Gulf of Maine, USA
}

\author{
Bruce J. Barber ${ }^{1}$, R. Getchell ${ }^{2}$, S. Shumway ${ }^{2}$, D. Schick ${ }^{2}$ \\ ${ }^{1}$ Department of Oyster Culture, Cook College/NJAES, Rutgers University, Shellfish Research Laboratory, PO Box 687 , \\ Port Norris, New Jersey 08349, USA \\ ${ }^{2}$ Maine Department of Marine Resources, Fisheries Research Laboratory, West Boothbay Harbor, Maine 04575, USA
}

\begin{abstract}
Quantitative and qualitative aspects of reproduction in the giant scallop Placopecten magellanicus (Gmelin) were compared between populations in the Damariscotta River (13 to $20 \mathrm{~m}$ depth) and the Gulf of Maine (170 to $180 \mathrm{~m}$ depth). Gonad weight $(\mathrm{p}<0.005)$ and gonad index $(p<0.01)$ were significantly greater in the shallow-water population during the period of gametogenesis. Oocytes of scallops in the shallow-water population developed gradually and spawning occurred in the fall. In spite of reduced gonadal production, scallops at the deep-water site completed gametogenesis. Oogenesis in the deep-water population was characterized by a greater initial rate of oocyte growth, resorption and a possible minor spring spawning, a period of redevelopment with continued resorption, and a later, more abrupt fall spawning. Gametogenesis was generally less synchronous among individuals in the deep-water population and oocytes were less dense within gonadal tissue. The reduction in gonad production at the deep-water site was manifested as a reduced fecundity (number of eggs), rather than reduced egg size, as mean oocyte diameters were similar for both populations. In spite of apparent energetic limitations, scallops at $180 \mathrm{~m}$ produce and spawn apparently viable ova, but in considerably lower numbers than those from shallower depths.
\end{abstract}

\section{INTRODUCTION}

Under optimal environmental conditions, reproduction occurs when surplus energy is available after maintenance requirements have been met. Under less favorable energetic conditions, maintenance energy demands are met along with some surplus for net growth, leaving a reduced portion for reproduction (Calow 1981, Bayne et al. 1983).

A reduction in the amount of energy available for reproduction can be manifested in several ways. In laboratory studies with Mytilus edulis, Bayne et al. (1985) found a positive linear relation between scope for growth and fecundity and Bayne et al. (1978) found a similar relation between scope for growth and egg size, and resultant energy content per egg. The ratio of gametic production to total production in $M$. edulis was less in populations experiencing environmental stress (Bayne \& Widdows 1978, Bayne \& Worrall 1980, Bayne et al. 1983). In general, marine bivalves subjected in nature to less favorable nutritive conditions during gametogenesis produce less gametogenic material, with the reduction being related to the severity of the stress (Bayne et al. 1983).

This relationship between available energy and reproduction appears to hold for the giant scallop placopecten magellanicus (Gmelin). With increasing depth of occurrence (10 to $31 \mathrm{~m}$ ) in Newfoundland, scallops exhibited a reduced reproductive output (MacDonald \& Thompson 1985b, 1986) and a reduced reproductive effort (MacDonald et al. 1987). It was concluded that the reduction in measured food availability with increasing depth was a primary factor regulating reproductive output in this species (MacDonald \& Thompson 1985a, b, 1986). Similarly, G. Robert \& M. Lundy (Halifax, N. S., Canada; pers. comm.) noted a reduction in gonad index in scallops collected from depths $>90 \mathrm{~m}$ compared to those from $<90 \mathrm{~m}$.

A population of Placopecten magellanicus occuring in even greater depths $(170$ to $180 \mathrm{~m})$ in the Gulf of Maine is currently being exploited commercially (Shumway \& Schick 1987). Compared to a population 
from shallower water $(13$ to $20 \mathrm{~m})$, the deep-water scallops are characterized by a reduced shell weight, less meat weight per unit shell height, a lower rate of growth and calculated maximum size, and smaller gonads, all indicative of nutritional stress (Gould 1981, Serchuk \& Rak 1983, Schick et al. 1987). The object of this study was to quantitatively and qualitatively compare reproduction in these populations so that observed relationships between depth of occurrence and fecundity in $P$. magellanicus could be further elucidated.

\section{METHODS}

Both shallow-water (Damariscotta River, Maine, USA, $43^{\circ} 51.26^{\prime} \mathrm{N}, 69^{\circ} 34.0^{\prime} \mathrm{W} ; 13$ to $20 \mathrm{~m}$ ) and deep-water (Gulf of Maine, $43^{\circ} 26.5^{\prime} \mathrm{N}, 69^{\circ} 33.3^{\prime} \mathrm{W}$; 170 to $180 \mathrm{~m}$ ) scallop populations were sampled at approximate monthly intervals for 1 yr beginning in January 1986. Scallops were collected at the shallow-water site by divers and at the deep-water site by trawlers. No sample was collected from the deep-water location in February, and in all but the January shallow-water sample (when $\mathrm{n}=14$ ), samples consisted of 10 males and 10 females. Individuals were selected for similar size (overall shell height ranged from 85 to $137 \mathrm{~mm}$ and sample means ranged from $93.6 \pm 7.8$ to $123.0 \pm 4.8 \mathrm{~mm}$ ). Scallops greater than $80 \mathrm{~mm}$ in shell height are generally considered to be sexually mature (Serchuk \& Rak 1983).

Scallops were shucked, drained, blotted dry, and then weighed whole. The gonads were removed, blotted, and weighed separately. Corresponding dry weights of whole scallop and gonadal tissues were obtained using the non-linear regressions provided by Schick et al. (1986) for both of these populations. A separate seasonal equation relating wet weight to dry weight was used for both whole scallop and gonad tissues. Gonads were fixed in Bouins solution and a cross section of tissue was dehydrated, cleared, embedded, and stained with hematoxylin and eosin for histological examination.

Reproductive development in both shallow-water and deep-water populations was quantified by obtaining sample means for the following. (1) Gonadal mass was expressed as gonad dry weight (Barber \& Blake 1981, 1983). (2) A gonadal index was calculated as the ratio of gonad dry weight to total tissue dry weight $\times 100$ (Barber \& Blake 1981, 1983). Oocyte diameters of the 10 females ( $n=50$ individual $^{-1}$ ) were obtained from the histological sections (Barber \& Blake 1981, 1983) using the Bioquant Image Analysis System. Only oocytes sectioned through the nucleus were measured. Additional qualitative information obtained from the histological sections was obtained for verification of reproductive events.

\section{RESULTS}

Seasonal variation in gonadal mass was considerably greater in the shallow-water population. In addition, mean gonad weight was greater in the shallow-water population than in the deep-water population throughout the year (Fig. 1). Mean gonad weight remained

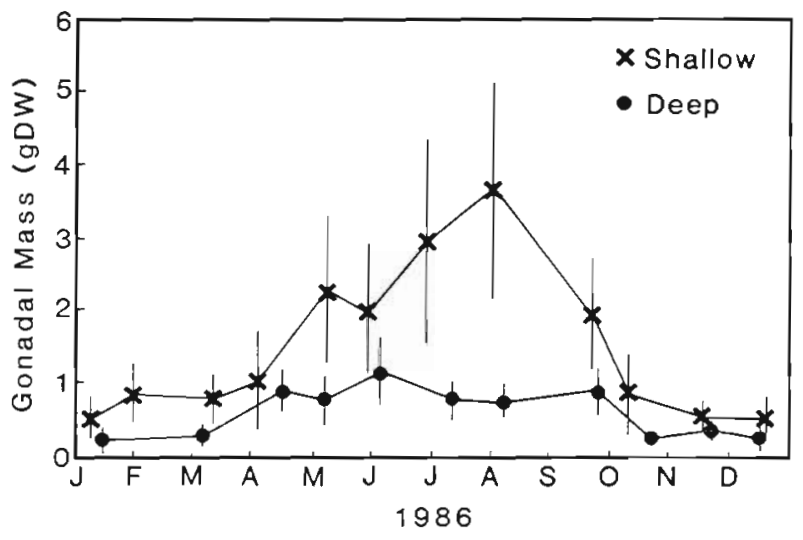

Fig. 1. Placopecten magellanicus. Gonadal mass (mean \pm 1 SD) from shallow-water and deep-water sites

constant from January through March in both populations but began to increase in April. Mean gonad weight in the shallow-water population increased from May until August when a maximum of $3.6 \pm 1.4 \mathrm{~g}$ was attained. In September and again in October mean gonad weight decreased, reaching a minimum of $0.5 \pm$ $0.2 \mathrm{~g}$ by December. Mean gonad weight in the deepwater population increased gradually from March through June, reaching a maximum of $1.2 \pm 0.4 \mathrm{~g}$. A slight decrease occurred in July, with values remaining essentially the same through September. A slight decrease also occurred in the deep-water population in October, and a minimum value of $0.2 \pm 0.1 \mathrm{~g}$ was found in December. Thus in both populations, gonad production was confined to the period of March through October. Mean gonad weight was significantly greater in the shallow-water population in the months of March and May through December (ANOVAI, $\mathrm{p}<0.005)$.

Annual cycles of gonadal index also occurred at both sites, but seasonal differences were more pronounced in the shallow-water population (Fig. 2). Mean gonad index in both populations increased gradually from January through April. Mean gonad index continued to increase in the shallow-water population until August, when a maximum of $18.4 \pm 4.9 \%$ was reached. Mean gonad index then decreased sharply in September and October to values below $3.0 \pm 0.7 \%$ which were maintained throughout the rest of the year. In the deepwater population, mean gonad index decreased 


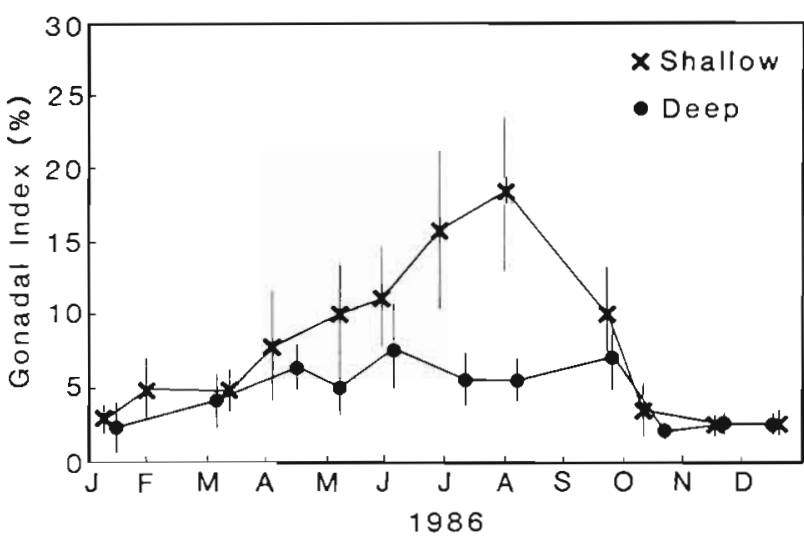

Fig. 2. Placopecten magellanicus. Gonadal index (mean \pm 1 SD) from shallow-water and deep-water sites

slightly between April and May, but reached a maximum of $7.8 \pm 2.9 \%$ in June. A decrease in July was followed by an increase in September and then a sharp decrease to a minimum of $2.1 \pm 0.4 \%$ in October. Mean gonad index was significantly greater in the shallow-water population for the months of May through October (ANOVA I, p < 0.01).

Both scallop populations exhibited annual cycles of mean oocyte diameter (Fig. 3). The mean oocyte

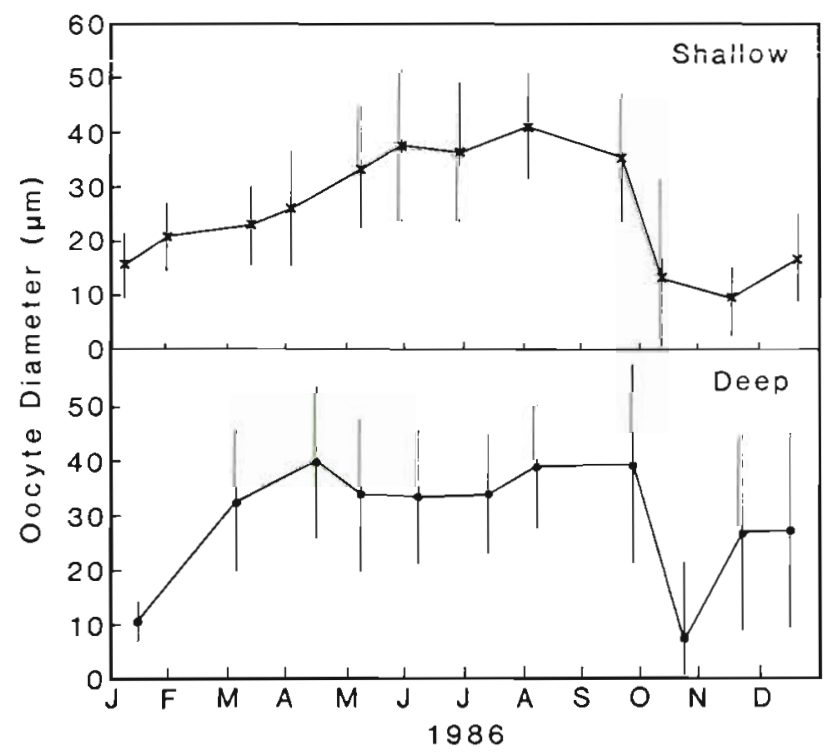

Fig. 3. Placopecten magellanicus. Oocyte diameter (mean \pm 1 $\mathrm{SD}$ ) from shallow-water and deep-water sites

diameter of the shallow-water population increased gradually from January to August, when a maximum mean diameter of $41.1 \pm 9.8 \mu \mathrm{m}$ was attained. Mean diameter in the shallow-water population then decreased slightly in September and more drastically in October, and remained below $20 \mu \mathrm{m}$ for the remainder of the year Initially, the mean oocyte diameter of the deep-water population increased at a greater rate than the shallow-water population, reaching a peak of $39.7 \pm 14.1 \mu \mathrm{m}$ in April. This was followed by a slight decrease in May, with means then remaining near $33 \mu \mathrm{m}$ from May through July. A second peak of $39.2 \pm$ $18.4 \mu \mathrm{m}$ was obtained in September in the deep-water population. This was followed by a significant decrease (ANOVA I, p < 0.05) in October, and a subsequent increase in November and December. No significant differences in mean oocyte diameter were detected between the 2 populations at any time during the year (ANOVA I, p < 0.05). The largest ova measured were 93.6 $\mu \mathrm{m}$ in the shallow-water population and $89.0 \mu \mathrm{m}$ in the deep-water population.

Mean gonad weight, gonad index and oocyte diameter were reflective of actual gametogenic events occurring at the 2 depths. The shallow-water population was in recovery in December and January, initiated primary oogenesis in February, secondary oogenesis in March, and vitellogenesis after June. Spawning and resorption of mature ova was evidenced in September and to a greater extent in October. By October and November shallow-water scallops were mostly spent. In the deepwater population oogenesis proceeded at a greater rate than the shallow-water population from January through April. In May, however, extensive resorption of oocytes was evidenced. Some follicles were also partially empty, apparently as the result of a minor spawning. From June through August, oocytes slowly redeveloped, although resorption continued to be observed. By September, when the maximum mean diameter was recorded, spawning and resorption of mature ova had begun. In October deep-water scallops were primarily spent, but in November and December the sample consisted of scallops that were either completely spent, resorbing ova, or recovering. Gametogenic development was relatively homogenous within an individual. The seemingly large standard deviations associated with the mean oocyte diameters were primarily the result of differences between individuals. The deep-water population had generally greater standard deviations associated with its mean oocyte diameters because gametogenesis in this population was less synchronous than in the shallow-water population. Another observation which is not reflected in the oocyte measurements is that follicles containing oocytes were generally less dense in gonadal tissue of scallops from the deep-water population.

Both gonad weight and gonad index determinations indicated that the shallow-water scallops produced a considerably greater amount of gonadal material, not 
only in terms of actual mass, but also as a proportion of total body mass. However, the lack of energy allocated to reproduction in the deep-water population was not reflected as a reduction in average egg size. Rather the quantitative differences in gonad weight between the 2 populations were manifested as a reduced fecundity in the deep-water population, as opposed to a reduction in average egg size.

\section{DISCUSSION}

The shallow-water (13 to $20 \mathrm{~m}$ ) population of Placopecten magellanicus exhibits what can be considered a typical reproductive cycle for this species. Gamete development, as indicated by all 3 quantitative measures, begins in March and continues through August, when mature gametes are present in highest proportion. Spawning begins in September and continues through October. The timing of gametogenic events and the quantitative aspects of gonad production in this population are similar to those reported previously (Naidu 1970, Thompson 1977, Robinson et al. 1981, MacDonald \& Thompson 1986), allowing for site and time-specific variations in environmental conditions.

The reproductive cycle of the deep-water (170 to $180 \mathrm{~m}$ ) population varies considerably from that in the shallow-water population. Although gametogenesis is confined to basically the same time period (March through October), gonad weight and gonad index are considerably lower than in the shallow-water population. Qualitatively the deep-water population is more developed in March and April, undergoes resorption with possible minor spawning in May, redevelops with continual resorption from June through August, and then spawns more abruptly in October, a month later than in shallow water. Thus the timing of reproductive events as well as the amount of gametogenic material produced in the deep-water population differs from that in the shallow-water population.

Although less energy is allocated to gametogenesis in the deep-water population, the relative size of individual oocytes is not affected. This is in agreement with the observation of MacDonald \& Thompson (1986), who found no difference in the diameter of spawned eggs from depths of 10 and $31 \mathrm{~m}$. Thus when faced with the apparently less favorable conditions associated with increasing depth, the strategy of Placopecten magellanicus is to produce fewer eggs without sacrificing egg size and potential larval survival (see Kraeuter et al. 1982). In this study the female gonad wet weight loss upon spawning ranged from $5.0(\bar{X}-1 \mathrm{SD})$ to 10.5 $(\bar{X}+1 S D) g$ for the shallow-water population and 2.2 $(\bar{X}-1 S D)$ to $3.8(\bar{X}+1 S D) g$ for the deep-water popu- lation (both spawnings). Dividing by the wet weight of an average ova $\left(1.6 \times 10^{-7} \mathrm{~g}_{i}\right.$ Langton et al. 1987) results in fecundities ranging from 3.1 to $6.6 \times 10^{7}$ eggs per female in the shallow-water population and 1.4 to $2.4 \times 10^{7}$ eggs per female in the deep-water population, almost a 3 -fold difference. The calculated fecundity for the deep-water site is probably an overestimate considering the reduced density of oocytes and the greater degree of resorption. This reduction in fecundity coupled with a greater spawning asynchrony could potentially reduce the reproductive viability of the deep-water population.

It is unlikely that depth per se is the cause of reduced fecundity at the deep-water site, as reproduction in marine invertebrates is not depth limited. However, with increasing depth, a decrease in both temperature and food supply resulted in reduced reproductive activity in Placopecten magellanicus (MacDonald \& Thompson, 1985a, b, MacDonald et al. 1987). Similarly, differences in temperature and/or food supply between the shallow (13 to $20 \mathrm{~m}$ ) and deep-water (170 to $180 \mathrm{~m}$ ) sites in this study could be responsible for the differences in fecundity.

In marine bivalves, temperature influences the pattern of the reproductive cycle and its corresponding gametogenic changes depending upon the thermal history of the species and the geographic distribution of the population (Bayne 1975, Sastry 1979). Some estuarine species have a characteristic minimum threshold temperature that must be attained before gamete differentiation will begin, with the subsequent rate of development being temperature dependent (Sastry 1979). In contrast, temperature has relatively little influence on species inhabiting areas of continually low temperature (Vahl 1978, Stockton 1984). Presumably Placopecten magellanicus experiences relatively low temperatures at the deep-water site. However, since gonad differentiation in this species occurs at temperatures as low as $-1{ }^{\circ} \mathrm{C}$ (Thompson 1977, MacDonald \& Thompson 1986) and gametogenesis was completed in the deepwater population of this study, low temperature does not appear to be the primary factor responsible for the reduced fecundity.

Reproduction is ultimately limited by food supply, as the amount of energy above the maintenance requirement is more dependent on food availability than temperature (Bayne \& Newell 1983). Food supply can regulate both the timing of the reproductive cycle and the amount of gametogenic material produced (Bayne 1975, Sastry 1979). Nutrient stress during gametogenesis can result in the production of fewer and/or smaller ova having reduced energy content (Bayne et al. 1978), and if great enough, gametes will be resorbed (Bayne et al. 1982). Local food availability 
also explains differences in reproduction seen between populations of Mytilus edulis (Bayne \& Widdows 1978, Bayne \& Worrall 1980, Newell et al. 1982, Bayne et al. 1983). For Placopecten magellanicus, the initiation of gametogenesis is strongly linked to food availability (Thompson 1977, Robinson et al. 1981, MacDonald \& Thompson 1985a, 1986). Differences in the amount of gonad material produced are also correlated to available food supply, not only between sites (and depths) but between years at the same site (MacDonald \& Thompson 1985a, b, MacDonald et al. 1987). Thus it appears that the greater the energy content of available food (probably on an annual basis), the greater the gametogenic production in $P$. magellanicus.

Although no quantitative estimates of food supply are available for the 2 areas sampled in this study, qualitative data indicate that the trends established between reproduction and depth (i.e. food supply) between 10 and $90 \mathrm{~m}$ are continued to $180 \mathrm{~m}$. Shumway et al. (1988) found a preponderance of benthic phytoplankton species in the guts of scallops from the deep-water site, indicating that relatively little surfacederived primary productivity is available at $180 \mathrm{~m}$. As suggested by MacDonald \& Thompson (1985b) surface primary productivity would more readily be available to bottom-dwelling scallops at shallower depths where greater mixing of the water column occurs. Thus a lack of available energy would best account for the lower gonad production, greater degree of resorption, and lower fecundity exhibited by the deep-water scallops.

This study corroborates previous work suggesting that a strong relationship exists between depth-related food availability and reproductive output in Placopecten magellanicus (MacDonald \& Thompson 1985a, b, 1986, MacDonald et al. 1987). The giant scallop could be considered an energetic opportunist with respect to reproduction. Gonad differentiation occurs whenever enough energy is available, and final gametogenic production is determined by the prevailing energetic conditions. In spite of a level of energetic stress that considerably reduces net growth, scallops at $180 \mathrm{~m}$ still allocate some energy to reproduction. However, the resultant lowered fecundity reduces the likelihood that the deep-water population is self-sustaining. Differences in food supply between times and places might thus be one factor responsible for the highly variable recruitment characteristic of this species.

Acknowledgements. We are indebted to the Department of Marine Resources dive team and Kilo Pinkham for the collection of scallops. We also thank J. Barter and J. Stahlnecker for technical assistance. N. Blake and B. MacDonald provided valuable comments on the manuscript. This is NJAES publication no. D-32001-1-87, supported by funds from the states of Maine and New Jersey.

\section{LITERATURE CITED}

Barber, B. J., Blake, N. J. (1981). Energy storage and utilization in relation to gametogenesis in Argopecten irradians concentricus (Say). J. exp. Mar. Biol. Ecol. 52: 121-134

Barber, B. J., Blake, N. J. (1983). Growth and reproduction of the bay scallop, Argopecten irradians (Lamarck), at its southern distributional limit. J. exp. mar. Biol. Ecol. 66: $247-256$

Bayne, B. L. (1975). Reproduction in bivalve molluscs under environmental stress. In: Vernberg, F. J. (ed.) Physiological ecology of estuarine organisms. University of South Carolina Press, Columbia, p. 259-277

Bayne, B. L., Brown, D. A., Burns, K., Dixon, D. R., Ivanovici, A., Livingstone, D. R., Lowe, D. M., Moore, M. N., Stebbing, A. R. D., Widdows, J. (1985). The effects of stress and pollution on marine animals. Praeger Publishers, New York

Bayne, B. L., Bubel, A., Gabbott, P. A., Livingstone, D. R., Lowe, D. M., Moore, M. N. (1982). Glycogen utilisation and gametogenesis in Mytilus edulis L. Mar. Biol. Lett. 3: 89-105

Bayne, B. L., Holland, D. L., Moore, M. N., Lowe, D. M., Widdows, J. (1978). Further studies on the effects of stress in the adult on the eggs of Mytilus edulis. J. mar. biol. Ass. U.K. 58: 825-841

Bayne, B. L., Newell, R. C. (1983). Physiological energetics of marine molluscs. In: Saleuddin, A. S., Wilbur, K. M. (eds.) The Mollusca, Vol. 4. Academic Press, New York, p. $407-515$

Bayne, B. L., Salkeld, P. N., Worrall, C. M. (1983). Reproductive effort and value in different populations of the marine mussel, Mytilus edulis L. Oecologia (Berl.) 59: 18-26

Bayne, B. L., Widdows, J. (1978). The physiological ecology of two populations of Mytilus edulis L. Oecologia (Berl.) 37 $137-162$

Bayne, B. L., Worrall, C. M. (1980). Growth and production of mussels Mytilus edulis from two populations. Mar. Ecol. Prog. Ser. 3: 317-328

Calow, P. (1981). Resource utilization and reproduction. In: Townsend, C. R., Calow, P. (eds.) Physiological ecology. Blackwell Scientific Publications, Oxford, p. 245-270

Gould, E. (1981). Field stress in the scallop Placopecten magellanicus. Coun. Meet. int. Counc. Explor. Sea C.M.ICES/E 7, p. 16

Kraeuter, J. N., Castagna, M., van Dessel, R. (1982). Egg size and larval survival of Mercenaria mercenaria (L.) and Argopecten irradians (Lamarck). J. exp. mar. Biol. Ecol. 56: 3-8

Langton, R. W., Robinson, W. E., Schick, D. (1987). Fecundity and reproductive effort of sea scallops Placopecten magellanicus from the Gulf of Maine. Mar. Ecol. Prog. Ser. 37: $19-25$

MacDonald, B. A., Thompson, R. J. (1985a). Influence of temperature and food availability on the ecological energetics of the giant scallop Placopecten magellanicus. I. Growth rates of shell and somatic tissue. Mar. Ecol. Prog. Ser. 25: 279-294

MacDonald, B. A., Thompson, R. J. (1985b). Influence of temperature and food availability on the ecological energetics of the giant scallop Placopecten magellanicus. II. Reproductive output and total production. Mar. Ecol. Prog. Ser. 25: 295-303

MacDonald, B. A., Thompson, R. J. (1986). Influence of temperature and food availability on the ecological energetics of the giant scallop Placopecten magellanicus. III. Physiological ecology, the gametogenic cycle and scope for growth. Mar. Biol. 93: 37-48 
MacDonald, B. A., Thompson, R. J., Bayne, B. L. (1987). Influence of temperature and food availability on the ecological energetics of the giant scallop Placopecten magellanicus. IV Reproductive effort, value and cost. Oecologia (Berl.) 72: 550-556

Naidu, K. S. (1970). Reproduction and breeding cycle of the giant scallop Placopecten magellanicus (Gmelin) in Port au Port Bay, Newfoundland. Can. J. Zool. 48: 1003-1012

Newell, R. I. E., Hilbish, T. J., Koehn, R. K., Newell, C. J. (1982). Temporal variation in the reproductive cycle of Mytilus edulis L. (Bivalvia, Mytilidae) from localities on the east coast of the United States. Biol. Bull. mar. biol. Lab., Woods Hole 162: 299-310

Robinson, W. E., Wehling, W. E., Morse, M. P., McLeod, G. C. (1981). Seasonal changes in soft-body component indices and energy reserves in the Atlantic deep-sea scallop, Placopecten magellanicus. Fish. Bull. U.S. 79: 449-458

Sastry, A. N. (1979). Pelecypoda (excluding Ostreidae). In: Giese, A. C., Pearse, J. S. (eds.) Reproduction of marine invertebrates, Vol. V. Academic Press, New York, p. 113-292

Schick, D. F., Shumway, S. E., Hunter, M. (1986). Allometric relationship and growth in Placopecten magellanicus: the effects of season and depth. Malacological Rev. (in press)

Schick, D. F., Shumway, S. E., Hunter, M. (1987). A comparison of growth rate between shallow water and deep water populations of scallops, Placopecten magellanicus (Gme- lin, 1791) in the Gulf of Maine. Bull. Am. Malacolog. Soc. (in press)

Serchuk, F. M., Rak, R. S. (1983). Biological characteristics of offshore Gulf of Maine sea scallop populations: size, distributions, shell height-meat weight relationships and relative fecundity patterns. Nat. Mar. Fish. Serv., Woods Hole Lab., Ref. Doc. No. 83-07

Shumway, S. E, Schick, D. F. (1987). Variability of growth, meat count and reproductive capacity in Placopecten magellanicus: are current management policies sufficiently flexible? Coun. Meet. int. Counc. Explor. Sea C.M. ICES/K 2, p. 26

Shumway, S. E., Selvin, R., Schick, D. F. (1988). Food resources related to habitat in the scallop, Placopecten magellanicus, (Gmelin, 1791): a qualitative study. J. Shellfish Res. (in press)

Stockton, W L. (1984). The biology and ecology of the epifaunal scallop Adamussium colbecki on the west side of McMurdo Sound, Antarctica. Mar. Biol. 78: 171-178

Thompson, R. J. (1977). Blood chemistry, biochemical composition, and the annual reproductive cycle in the giant scallop, Placopecten magellanicus, from southeast Newfoundland. J. Fish. Res. Bd Can. 34: 2104-2116

Vahl, O. (1978). Seasonal changes in oxygen consumption of the Iceland scallop (Chlamys islandica [O. F, Müller]) from $70^{\circ} \mathrm{N}$. Ophelia $17 \quad 143-154$

This article was presented by Professor R. C. Newell; it was accepted for printing on November 25, 1987 